\title{
Political Framework of Green New Deal: A comparative analysis of the EU and US proposals
}

\section{Taedong Lee, Myungsung Kim, Natalie Chifamba}

\begin{abstract}
Green New Deal (GND) proposals are suggested as a solution to cope with climate emergency, economic recession, and social inequality. This study aims to conceptualize GNDs through the political questions of who gets what, why, and how. This research defines the politics of GND as a government's stimulus policy to tackle climate change, economic downturn, and inequality by building up sustainable infrastructure, industries, and communities through investment, job creation, and innovation. The politics of the GND framework consists of actors, aims, contents, and measures. By applying this framework, empirical analyses examine the similarities and differences in the GND proposals of the EU and the US. This finding suggests that varying comprehensiveness and concreteness are presented in these proposals. The preliminary analysis demonstrates that measures for funding should be identified for implementing effective GND plans. Research applying the political analysis framework into recently announced Korean GND would contribute to enhancing the policy plan and implementation process.
\end{abstract}

Keywords: Green New Deal, Climate Change Politics, Just Transition, Carbon Neutral, USA, EU

\footnotetext{
***Taedong Lee(tdlee@yonsei.ac.kr) is professor at the Department of Political Science and International Relations in Yonsei University, Seoul. His areas of research include global and subnational environmental politics and policy, NGO politics, international political economy and social network analysis. His articles have appeared in journals including Policy Sciences, Voluntas, Nonprofit and Voluntary Sector Quarterly, Review of Policy Research, Journal of Cleaner Production, Policy Studies Journal, and Global Environmental Politics.

* Myungsung Kim received Master of Arts degree in Political Science from Yonsei University with research focus on Environmental Politics.

* Natalie Chifamba received Master of Arts degree in Political Science from Yonsei University with research focus on Environmental Politics.

This study is supported by the National Research Foundation of Korea (2019S1A5A2A01047251).
}

The Korean Journal of International Studies Vol.19, No.2 (August 2021), 221-246 


\section{Introduction}

The protracted climate emergency, coupled with economic recession, as well as newly emerging crises like the coronavirus pandemic, require paradigm changes in response to the complex crisis (Albert 2020). A Green New Deal (GND) recently proposed in the political arena aims to tackle three major issues: environmental sustainability, economy, and social inequality. Based on the US New Deal policy which aimed to overcome the Great Depression in the 1930s, the 'Green' segment added the roles of the government and society to reduce greenhouse gas (GHG) emissions and environmental pollution through innovative and sustainable industries, jobs, and infrastructure (Tienhaara 2016).

Barbier (2010) urged that G20 countries need to adopt a global Green New Deal as China and South Korea have invested in the stimulus package for the environment. Comparing GND supporters' and eco-socialists' perspectives toward GND, for instance, Asici and Bünül (2012) concluded that the critical approaches of eco-socialists and reformists are complementary rather than substitutes when considering a transformative and green 'step-forward' agenda. Despite the increasing public, scholarly, and policy attention on green growth and the economy (Tienhaara 2016), few systematic studies have defined and compared current GND proposals.

This study aims to contribute to conceptualizing the politics of the GND to provide a comparative analytic framework, and to empirically compare the Green New Deal proposals from the United States (U.S.) and the European Union (EU). Specifically, this research analyzed the U.S. Green New Deal Resolution (H.RES. 109) and the European Union's proposal for GND, the European Green Deal (EGD) (The European Green Deal 2020)ํ. This research compared two GND proposals proposed at the parliament to enable systematic comparison. This is because this paper aims to provide a practical framework for practitioners who are developing GND to improve and produce effective GND strategies. Our framework has been developed based on reviewing GND proposals and studies on green growth and sustainability. Particularly, this research uses the fundamental questions of politics; that is, who gets what, why, and how in analyzing and developing the GND framework. By answering these political questions, this study contributes to understanding the key components of the GND. A systemic comparison of the GND proposals allows us to identify the focus of different GND designs. Thus, this comparative study provides a tool to identify policy implications, combining environmental and economic policies.

\footnotetext{
${ }^{1}$ The European Green Deal has been adopted by the European Parliament on January 2020
} 
The next section discusses the varying concepts of the GND. Then, the framework of GND analysis is introduced. Furthermore, based on the framework, we analyze GNDs of the European Union and the United States. The final section discusses the contributions and policy implications of this study.

\section{Conceptualizing Green New Deal}

The Green New Deal has transformed over time but fundamentally it is a set of policy recommendations addressing climate change and environmental protection while revitalizing the economy. This uneasy combination of different factors has stemmed from the cognizance of Ecological Modernization that "business and environment are not opposing forces; instead, they are all of one piece(Luke 2009)."

While the Great Depression was the impetus for Roosevelt's lauded 1933 New Deal, the global recession of 2008 gave birth to the Green New Deal, coined by the Green New Deal Group (GNDG). Led by London based economists, journalists, and experts the three-pronged approach hinged on addressing global warming, the global financial crisis, and oil dependency, in part fulfilling what Barbier described as the need for the "international community to promote a mix of policies to sustain [this] global recovery and create jobs through reducing carbon dependency, ecological degradation and poverty (Barbier 2020)." The GNDG identified that a principal driver of the 2008 global financial crisis was an "unsustainable level of debt and consumption of energy and other resources (Tienhaara 2014)," and it sought to address this by looking at the energy sector and sustainability of the environment. The GNDG also identified wider implications for job creation and the facilitation of a robust economy. The combination of economic and environmental issues in 2008, therefore, determined that the GND was different from regular climate change or environmental protection policies; it not only sought to protect the environment but also to transform the economy. Popular discourse and political will for GNDs seemingly followed a downward trend from 2008 to 2018. In 2019, the deal once again came to the fore of global discourse under the perfect storm of an unprecedented global financial crisis and worsening climate conditions.

While the GND largely gained worldwide recognition, it garnered domestic infamy in different states in the United States of America, the infrastructural expense alone presented contested cost projections. To illustrate, modernizing the national grid was projected by the American Action Forum to cost up to 5.4 trillion dollars (Holtz-Eakin et al. 2019). Translated to cost per household, 
approximately thirty-nine thousand dollars would be required for the decade-long period from 2020 to 2029 (Holtz-Eakin et al. 2019). However, other economists and academics have fielded counter approaches to understanding financing surrounding the GND. Scholars Yeva Nersisyan and Randall Wray recently argue that even estimating the cost of the GND in financial terms is fundamentally flawed(Nersisyan and Wray 2020). They instead urge the GND to be measured in terms of real resources as this gives a "careful accounting of the resources the GND will require (Nersisyan 2020)."

Conceptually, Green New Deals have been persistently provocative for decades. Predating the EU's Green Deal, the UK Green New Deal also evoked the interest of scholarship. Ann Pettifor in the book, the case for the Green New deal argues that GND should not be captured merely as ideas or even policy proposals but essentially comprehensive plans (Pettifor 2020). Her determined position captures these plans as a lasting solution to both climate and global economic breakdown which should not be seen as separate but intimately intertwined sectors fueled by a global capitalistic society.

Theoretically, scholars like Chohan argue that GNDs are not only just conceptually or practically derived, but have theoretical foundations stemming from various socio-ecological disciplines. Therefore, these foundations are worthy of scrutiny to understand the philosophical underpinnings and influences of the proposals. Chohan evaluates the various perspectives of ecofeminists, and ecological-economists, to help locate which political forces support or resist the deals, and how these theoretical approaches will come to situate global and local narratives on the practicability and next steps of GNDs.

Bloomfield and Steward (2020) approach comparison of the deals from the political ideologies that shaped them and the times that have shaped their respective prospects. They indicate the different ebb and flows of the Green New Deal in Europe and America and place them as temporal phenomena and define the potential of the deals according to their capacity to solve the emergent issues of their time. This then frames the current Covid-19 pandemic as one such urgent problem and opportunity to investigate if the potential of the ideological GND can translate into viable politics (Bloomfield and Steward 2020).

These perspectives all describe the growing importance of discourse surrounding GND. GNDs all set ambitious goals for the near future, which have in turn been transformed due to the newly emerged complexity of the Covid-19 pandemic. This study hopes to answer key political questions to facilitate comprehension of the focal parts of the GND to further enrich understanding of the interplay between politics and GND practicability. Furthermore, this study is uniquely situated to do this because, first, conceptually, there have been few 
studies on the politics of GNDs. Second, studies that have been conducted expectedly came after the first flurry of interest generated after the 2008 global financial crisis. Over a decade, there has not been a substantial advancement on the topic of the GND in spite of the implications and impact of the deals in the political sphere. Third, few studies empirically compare and analyze the current GND proposals from political perspectives. This study contributes to filling these conceptual and empirical gaps by proposing the framework of politics of GND.

While there have long been many policies intended to contribute to the green economy, the GND has components that differentiate it from generally applied concepts such as sustainable development and green growth. There is not enough attention paid to the GND, even though it now takes the center stage as a plausible sustainable recovery pathway across several sectors. Developing a systematic framework enables a practical analysis that will support future theoretical and scientific analysis of the GND.

\section{Politics of Green New Deal: who gets what, why, and how}

Despite an effort to suggest a toolbox for GND designs (Dauncey 2019), an attempt to suggest a framework to answer the most fundamental questions of GND; who gets what, why, and how is lacking. Therefore, this research proposes a framework composed of who (actors), why (aims), what (contents), and how (measures) based on Harold Laswell's definition of politics (Lasswell 1936). This performs a comparative analysis of how GNDs' strategies and policy targets vary across states to tackle shared triple economic, ecological, and social crises (Aşici and Bünül 2012). Each category is followed by subcategories and specific questions that represent GND concepts. Each subcategory is based on the review of ten GND proposals analyzed by Dauncey (Dauncey 2019) and the literature on green growth and sustainability. ${ }^{2}$ Our framework is not intended to distinguish GNDs from other green capital concepts; rather, our framework allows practitioners and academics to reevaluate and improve GND components to ensure the delivery of economically effective, ecologically sustainable, and socially inclusive GND. Through this process, our framework can contribute to the existing research debate on whether burgeoning and implemented GNDs are another economic development plan with green rhetoric in addressing environmental, economic, and social crises. Furthermore, it contributes to practitioners' and academics' identification of the components included and

${ }^{2}$ OECD, 2011; Hickel et al., 2019; O’Neill, 2020; Tienhaara, 2016 
excluded to develop an effective GND strategy.

This research defines Green New Deal as a government stimulus policy to tackle climate change, economic downturn, and inequality by building up sustainable infrastructure, industries, and communities through investments, job creation, and innovations. The first component of our framework, the 'who' answers the question of which government organization or body is a policy initiator and which industry, social group, or community are the policy targeted. Second, the 'why' question addresses the aim of the GND and answers the question, what does the GND aim to accomplish? Third, the 'what' question refers to the contents of GND and answers the question, what will be done to accomplish the aims of GND? Lastly, the 'how' question refers to the method of delivering the contents of GND.

Table 1. Politics of the Green New Deal Framework

\begin{tabular}{|c|c|c|}
\hline Category & Sub-Category & Question \\
\hline \multirow{5}{*}{ Who (Actors) } & \multirow{3}{*}{ Policy Initiator } & $\begin{array}{l}\text { Does the Green New Deal (GND) proposal designate a government } \\
\text { body (or bodies) to deliver GND policies? }\end{array}$ \\
\hline & & $\begin{array}{l}\text { Does the proposal demonstrate its willingness to reflect the opinions } \\
\text { of academics, businesses, civil society, and labor unions in its } \\
\text { development? }\end{array}$ \\
\hline & & Does the proposal address the role of local/municipal governments? \\
\hline & \multirow{2}{*}{ Policy Target } & $\begin{array}{l}\text { Does the proposal designate a specific industry (or business sector) } \\
\text { and community to be developed to meet the GND aims? }\end{array}$ \\
\hline & & $\begin{array}{l}\text { Does the proposal designate vulnerable social groups or communities } \\
\text { to raise climate change resilience, equality, and economic } \\
\text { competitiveness? }\end{array}$ \\
\hline \multirow{7}{*}{$\begin{array}{l}\text { Why } \\
\text { (Aims) }\end{array}$} & \multirow{3}{*}{$\begin{array}{l}\text { Climate Change } \\
\text { Mitigation and } \\
\text { Adaptation }\end{array}$} & $\begin{array}{l}\text { Does the proposal set goals for carbon neutrality, net-zero } \\
\text { greenhouse gas emissions, or decarbonization of the economy by } \\
2050 \text { ? }\end{array}$ \\
\hline & & $\begin{array}{l}\text { Does the proposal aim to preserve biodiversity and environmental } \\
\text { conservation to mitigate and adapt to climate change? }\end{array}$ \\
\hline & & Does the proposal aim to raise climate change resilience? \\
\hline & \multirow{2}{*}{ Green Growth } & $\begin{array}{l}\text { Does the proposal aim to create long-term, sustainable, and quality } \\
\text { jobs? }\end{array}$ \\
\hline & & $\begin{array}{l}\text { Does the proposal aim to achieve green growth (decoupling natural } \\
\text { resource use while achieving economic growth)? }\end{array}$ \\
\hline & \multirow[b]{2}{*}{ Social Equality } & Does the proposal intend to lessen social inequality? \\
\hline & & $\begin{array}{l}\text { Is the proposal set to improve the standard of living by guaranteeing } \\
\text { basic needs including environment and stable energy? }\end{array}$ \\
\hline
\end{tabular}




\begin{tabular}{|c|c|c|}
\hline Category & Sub-Category & Question \\
\hline \multirow{9}{*}{$\begin{array}{l}\text { What } \\
\text { (Contents) }\end{array}$} & \multirow{2}{*}{$\begin{array}{l}\text { Infrastructure } \\
\text { building }\end{array}$} & $\begin{array}{l}\text { Does the proposal include plans to build the infrastructure required to } \\
\text { achieve climate change mitigation? }\end{array}$ \\
\hline & & $\begin{array}{l}\text { Does the proposal include municipal and community-based } \\
\text { infrastructure and housing building to raise climate change resilience? }\end{array}$ \\
\hline & \multirow[b]{2}{*}{ Energy Transition } & $\begin{array}{l}\text { Does the proposal integrate consumers from different social groups to } \\
\text { participate in the energy transition? }\end{array}$ \\
\hline & & $\begin{array}{l}\text { Does the proposal incorporate financial and legislative support for } \\
\text { business sectors in the energy transition such as renewable energy, } \\
\text { smart grids, energy storage, and electric train rails? }\end{array}$ \\
\hline & \multirow{2}{*}{$\begin{array}{l}\text { Restructuring the } \\
\text { economy }\end{array}$} & $\begin{array}{l}\text { Does the proposal address financial reform including tax reform to } \\
\text { achieve a carbon-neutral economy? }\end{array}$ \\
\hline & & $\begin{array}{l}\text { Does the proposal recognize the concept of a circular economy to } \\
\text { minimize waste and resource use? }\end{array}$ \\
\hline & \multirow{3}{*}{$\begin{array}{l}\text { Industry } \\
\text { Transition }\end{array}$} & $\begin{array}{l}\text { Does the proposal include public investment and legislative support to } \\
\text { transform the transportation sector into carbon-neutral while being } \\
\text { accessible to all social groups? }\end{array}$ \\
\hline & & $\begin{array}{l}\text { Does the proposal support farmers and ranchers to practice } \\
\text { sustainable land use to safeguard food availability while reducing } \\
\text { greenhouse emissions? }\end{array}$ \\
\hline & & $\begin{array}{l}\text { Does the proposal include efforts to transform the trade industry to be } \\
\text { sustainable while promoting social equality? }\end{array}$ \\
\hline \multirow{6}{*}{$\begin{array}{c}\text { How } \\
\text { (Measures) }\end{array}$} & Education & $\begin{array}{l}\text { Does the proposal include plans to educate the public to raise climate } \\
\text { change awareness? }\end{array}$ \\
\hline & Job Training & $\begin{array}{l}\text { Does the proposal include job training for workers and minority groups } \\
\text { to be included in the industry transition to ensure sustainable and equal } \\
\text { employment opportunities? }\end{array}$ \\
\hline & $\begin{array}{l}\text { Research and } \\
\text { Innovation }\end{array}$ & $\begin{array}{l}\text { Does the proposal recognize the importance of technological } \\
\text { advancement to meet the GND aims and include investment and } \\
\text { legislative support to research and development? }\end{array}$ \\
\hline & $\begin{array}{l}\text { International } \\
\text { Cooperation }\end{array}$ & $\begin{array}{l}\text { Does the proposal include a method to promote international } \\
\text { cooperation in climate change mitigation and industry transition? }\end{array}$ \\
\hline & \multirow[t]{2}{*}{ Funding } & $\begin{array}{l}\text { Does the proposal include funding sources and the mechanism of } \\
\text { public investment? }\end{array}$ \\
\hline & & Does the proposal incorporate private investment as a funding source? \\
\hline
\end{tabular}

Source: Made by authors

\section{Who (actors)}

A Green New Deal requires broad social consensus between various groups including public agencies, labor unions, businesses, financial sectors, and NGOs to achieve its aims. Thus, identifying who is included and excluded is a critical part of the systematic evaluation of the GND. Our framework divided the major actors of GND into two groups: policy initiator and target. The question concerning policy initiators asks whether and how the GND proposal designates government bodies to deliver GND policies. The proposed question inquires if 
GND identifies who will take responsibility and who the main player is in delivering the policies.

On the other hand, the framework also asks who are the policy targets? Policy target groups can be divided into three categories: 1) the general public (e.g., job creation, social benefits including clean air and water, and accessibility to electricity); 2) industry (e.g., agriculture, transportation, manufacturing, and renewable energy); and 3) community (e.g., low climate change resilience, low-income, and youth). To identify policy targets the question outlines whether the proposal designates specific industries (or business sectors) and communities to be developed to meet the GND aims. In many cases, government bodies and non-governmental actors are interacting to design and implement GND. Additionally, regardingsocial inequality, we pose the question of whether the proposal designates vulnerable social groups or communities to raise climate change resilience, equality, and economic competitiveness.

\section{Why (aims)}

The 'why' question is intended to specify the aims of the GND. The sub-categories are composed of climate change mitigation and adaptation, green growth, and social equality. Climate change mitigation and adaptation is an essential part of what makes a GND 'green (Bloomfield and Steward 2020).' The question addressed here is whether the GND aims to reduce greenhouse gas emissions drastically (e.g., carbon neutrality) to mitigate climate change (IPCC 2019). For climate adaptation, the question addresses whether the proposal aims to raise climate resilience (Lee and Lee 2016).

The subcategory green growth represents GND's aim to tackle economic difficulties such as unsustainable debt, high unemployment rate, and income inequality. Roosevelt's New Deal, the origin of GND, was based on Keynesian economics which argued that government investment and spending will stimulate the economy (Pettifor 2019). Like the New Deal, GND aims to overcome economic hardship through government investments that are needed to achieve climate mitigation and adaptation. After comparing GND, green growth, and degrowth, O'Neill argued that GND and green growth share the same environmental policies while green growth excludes progressive social policies included in GND (O'Neill 2020, 260). According to Hickel and Kallis (2020), green growth is "the promise that technological change and substitution will improve the ecological efficiency of the economy, and that governments can speed this process with the right regulations and incentives." To identify whether the GND addresses green growth, we pose the question of whether the proposal includes green growth. Moreover, a characteristic demonstrated by GND is its emphasis 
on creating quality jobs. Fitz (2014) has warned about the possibility of GND not creating full-time employments, arguing that it is the "greatest illusion that the FDR's New Deal solved unemployment." Therefore, the question of whether the proposal aims to create long-term, sustainable, and quality jobs is essential (Lee 2017). Lastly, the question about social equality addresses whether the proposal recognizes and intends to lessen social inequality.

\section{What (contents)}

The 'what' question refers to what needs to be accomplished to achieve the aims stated in the 'why' part. Thus, the four subcategories, infrastructure building, energy transition, restructuring the economy, and industry transition, are in connection with the aims. In the first question, infrastructure building, smart grids, renewable energy generations, and carbon zero transportation systems are applied as means to achieve green growth which is critical to climate change mitigation and adaptation aims (MacArthur et al. 2020). The second question addresses whether the proposal reflects the aim of achieving social equality by including municipal and community-based infrastructure and housing building to raise climate change resilience. In the second subcategory of the 'what'question, energy transition is essential in climate change mitigation and, therefore, is a major component of GND. As a result, a question on the role of consumers, technology, and legislative support to achieve energy transition has been raised. Third, restructuring the economy addresses whether the proposal includes the financial reform required to accomplish the aims stated above (Elliott 2008; Rifkin 2019). Lastly, industry transition addresses three industry sectors: agriculture, transportation, and trade. Transportation has been designated as one of the key sectors emitting a substantial amount of greenhouse gas (IPCC 2019). Also, the transition in agriculture and trade will play a crucial role in climate resilience and achieving green growth (WTO and UNEP 2018).

\section{How (measures)}

The 'how' question refers to measures used to deliver the aims and contents of the GND. The subcategories are composed of education, job training, research and innovation, international cooperation, and funding (United Nations Environment Programme 2008). First, the question about education is whether the proposal includes plans to educate the public to raise climate change awareness (IPCC 2014). Second, the next question identifies whether the proposal includes job training for workers and minority groups to be incorporated into the industry transition to ensure sustainable and equal employment opportunities. Without a sufficient supply of trained labor, green 
growth would not be feasible (Lee 2017; MacArthur et al. 2020). Thus, this question ensures that workers from the fossil fuel industry and minorities are included in the energy transition to achieve just transition. Third, the subcategory research and innovation is about whether the proposal recognizes the importance of investment and legislative support in innovative research to achieve technological advancement to fulfill the GND aims. Investment in technology is critical, but the lack of legislative support allowing adoption and implementation only lowers the effectiveness of GND funding in such research (Lee 2017). Fourth, international cooperation refers to whether the proposal includes a method to promote international cooperation in climate change and industry transitions. Climate change is a transnational issue that requires cooperation between states on knowledge and resource sharing, climate refugees, trade, aid, and tariffs for investment in fossil fuel. Lastly, the subcategory funding is about whether the proposal includes funding sources and the mechanism of public investment as well as whether the proposal incorporates private investment as a funding source (Rifkin 2019; Pettifor 2019; Galvin and Healy 2020).

\section{Case analysis of Green New Deal proposals}

To apply the politics of the GND framework, this study analyzes the GNDs of the EU and the U.S. These two cases have been chosen for three reasons. First, both GNDs share common but differentiated components that can be compared when applied to the politics of the GND framework. Particularly, the concreteness of the funding mechanism is emphasized. Second, both GNDs have been proposed through a formal political process in democratic politics. The EU Green Deal was proposed by the European Commission to the European Parliament and the European Council, while the US GND was proposed by Congress members to the Congress. Third, the EU Green Deal was adopted in the EU Parliament and now serves as an action plan under implementation (15-Jan-2020), but the US GND proposal failed on the motion to proceed in the Senate (26-Mar-2019). Comparing two cases would contribute to the application of the developed GND concept and analytic framework in varying contexts and contents.

To compare GNDs, we mainly used document analysis. Based on the politics of the GND framework, we asked each question to find answers in the formally proposed and publicly open document of the European Council's Green Deal Communication (COM(2019)640) and the US (H. RES. 109) Congress. 


\section{GND proposal: The United States}

In the United States, the Green New Deal was tabled in the $116^{\text {th }}$ sitting of Congress sponsored by Representative Alexandria Ocasio-Cortez and Senator Edward Markey in March 2019 (US Congress H. RES. 109). The development of the policy emanated from the Democratic Party that saw a need to outline a set of policies to revitalize the economy while addressing the growing national and international calls for a just transition (Newell and Mulvaney 2013) from the heavy fossil fuel-based dependence of the U.S. The deal called for a decade-long national mobilization that included ambitious socio-economic goals such as providing universal health care while transitioning the United States to using $100 \%$ renewable, zero-emission energy sources and attaining carbon neutrality.

\section{Who (actors)}

The US Green New Deal proposal outlines a distinct top-down approach in terms of mobilizing political will. The US GND puts the federal government as the principal initiator of policy. In addition, the US proposal recognizes the GND's principal catalyst as an intergovernmental organization report (IPCC 2018) and, looks at developing the proposal in consultation with "frontline and vulnerable communities, labor unions, worker cooperatives, civil society, academia, and business (US Congress H. RES. 109)." Furthermore, there is an emphasis on the application of science-based projects for enhancing biodiversity and supporting climate resilience. The approach is, therefore, stakeholder-centered from the standpoint of consultative engagement. Additionally, there is a reference to co-implementation with local government bodies. Question 4 addresses the policy targets and attempts to identify if the GND is succinct in its aims for specific industries and business sectors. The US GND is specific in its business and industry targets and identifies different levels of intervention for industry and business reform. Lastly, the US GND proposal emphasizes the economic and social transformation of vulnerable groups for a "fair and just transition to all communities and workers (US Congress H. RES. 109)" with an emphasis on indigenous people, communities of color, migrants, deindustrialized, poor and low-income workers, women, the elderly, the homeless, people with disabilities, and the youth.

\section{Why (aims)}

The aims of the Green New Deal ordinarily offer the justification for its creation. The US GND sets zero emissions as a goal to be attained within a decade from the date of its tentative implementation. This GND emphasizes delivering climate/environmental goals together with specific social justice aims. Without 
mention of preserving biodiversity and conservation, the US GND aims at sustainability. It emphasizes industry, climate, and community resilience, while it articulating building resilience against climate change disasters, to the extent of building and strengthening infrastructure to reflect infrastructural resilience. Part of the GND appeal is also centered on job creation potential, with an emphasis on green growth.

The US GND highlights the creation of high-wage and sustainable jobs as a motivation and bargaining chip in many aspects of the GND proposal. First, it is to restore the economic stability of the middle class. Second, it is a way of boosting local manufacturing and reducing 'exported' pollution. Third, it is considered a means of delivering economic transformation and improving the conditions and accountability structures of workers. Regarding decoupling natural resources use from economic growth, the US Green New Deal does not utilize the language of decoupling specifically. However, this decoupling can be possibly extricated from the overt proposal items that tackle the pressure on natural resources. The US GND caters to industries such as farming and the food industry and outlines the importance of restructuring these industries to be more sustainable in ensuring soil health and to work with farmers to 'remove pollution.' Regarding social inequality, the US GND is clear in the policies intended to address and remedy this subject area. One of the proposal's main goals is to drastically reduce social inequalities. The US GND is equally simple and ambitious in its goal to improve the standard of living. The GND aims to provide "all people in the US [with] high quality healthcare, affordable, safe and adequate housing, economic security, clean water, clean air, healthy and affordable food and access to nature (US Congress H. RES. 109).”

\section{What (contents)}

Getting into the nuts and bolts of the US Green New Deal involves addressing the various contents of infrastructure building, energy transition, restructuring the economy, and industry. This section identifies what the GND says about these important sectors and their prioritization. The US GND outlines a two-pronged approach to infrastructure intended to deliver a just transition.

Direct investment in industries of interest can bolster and encourage technology development and improvement in the hope that industry investment will stimulate industry innovation. The requisite infrastructure will be built, such as energy-efficient and clean buildings, smart grid technologies, and building high-speed rail.

The proposal approaches housing and building to ensure efficiency, resilience, and also access for vulnerable communities. The first set of standards 
refers to upgrading all buildings in the US GND and building new ones according to the standards ensuring safety, affordability, and sustainability through maximizing energy and water efficiency. The category of durability is unclear and may not directly refer to climate resilience. The second set of standards refers to the provision of affordable and high-quality housing for all people of the United States.

The GND does not outline energy consumers as a specific target but rather identifies that the power needs of the US should be met through $100 \%$ clean and renewable energy. Concerning the wider consultation of all aspects of the GND and each proposal point, the GND outlines that there would be consultations especially at the local government level with the vulnerable and frontline communities that would be considered end consumers. These consultations are intended to ensure a just energy transition in vulnerable, frontline communities. That leaves the question of how businesses fare. Reflecting on the increasing social inequality in the US, the GND plays the role of a policy imperative for just transition from congress. For example, the GND outlines an imperative for any infrastructure bills tabled at the congress to address climate change.

While addressing the restructuring of the economy, the framework identifies the importance of tax reform and the circular economy. However, this is one of the key areas that the US GND does not address. Financial reform or tax regimes are not mentioned in achieving a carbon-neutral economy. Nonetheless, there is an emphasis on increasing efficiency to control water and energy efficiency as well as waste management, but there is no specific material on the circular economy and the role it plays in reducing waste and improving resource efficiency. In terms of industry investment, there is mention of overhauling the transportation sector. The goal is to ensure that there are zero emissions from transportation and to increase "clean, affordable, and accessible public transit and high-speed rail (US Congress H. RES. 109).” Furthermore, farming and agriculture are significant target sectors of the US GND. Critical to the delivery of the deal is working with farmers to achieve zero emissions and to implement sustainable practices that preserve the health of the soil. The deal outlines a move to 'family farming' and sustainable farming with land-use practices in mind. The GND also outlines that this is a target group to 'remove' pollution in their industry.

Finally, the US GND includes references to trade as an important factor for achieving its goals. Trade falls under a regulatory aspect of the proposal and is strengthened and monitored to foster greater levels of procurement standards, whilst ensuring environmental protection. 
How (measures)

Lastly, the politics of the GND framework considers education, job training, research and innovation, international cooperation, and funding as key vehicles through which policy objectives are attained. These sectors all require a means of delivery. In terms of job training, the minority, frontline, and vulnerable communities are well referenced throughout the US GND, and they often provide justification for the interventions outlined in the proposal.

The GND itself is proposed to be implemented with the consultation of all the mentioned communities while also ensuring that the result is community buy-in, 'ownership' of GND projects and programs, leading the majority of the social projects through grass-root mobilization and participation. The proposal ensures providing not only access to high-quality jobs but also 'training and advancement opportunities to further guarantee parity for workers affected by the transition.

Turning to research and innovation, technological advancement is a conduit and well-recognized tool for achieving several goals in the US GND. The US GND does emphasize its importance by prioritizing investment in the technology sector while also engaging in international collaborative exchanges to propel greater investments and innovations. In a related manner, international cooperation is a gateway proposal for facilitating the exchange of technology, expertise, products, and funding. However, in the proposal, this collaboration has the specific aim of appointing the US as the international leader in climate issues as well as 'helping' other countries achieve GND with the aim of learning and replicating results in combating these crises.

Lastly, the funding mechanism is the linchpin of the GND proposal. The US GND mainly emphasizes the role of the federal government in creating an enabling policy environment. It may be largely speculative; however, the deal also hopes to create favorable investment opportunities and a business environment that can further foster the achievement of goals. There is also the goal of making public investments, particularly in research and development, specifically targeting clean and renewable technology and industries. Finally, the US GND heavily leans toward investments and creating investment opportunities rather than specifically outlining the categories of private investments and funding streams.

\section{GND proposal: The European Union}

The European Union, under the newly (December 2019) elected European Commission, also put forward a policy proposal under the auspices of the Green Deal and now serves as an implemented action plan. In the wake of the newly 
emerged Covid-19 global pandemic, this deal has received several calls for swifter integration into the recovery plans of the ailing economies of the EU. Measured against our framework, how does the EU GND perform on the scale of who, why, and what, and how does it deliver the Green Deal? It is important to keep in mind that this European Green Deal (EGD) is developed with a regional body rather than with specific nation-states, and it now excludes the UK from its ranks.

\section{Who (actors)}

The major policy initiator of the European Green Deal is the European Commission. The deal also outlines "citizens in all their diversity, with national, regional, local authorities, civil society and working closely with the EU's institutions and consultative bodies (European Commission 2019)."3 Nevertheless, the EU commission remains the principal actor in fostering 'deeply transformative policies.' Question 2 that seeks to evaluate the willingness to involve academia, business, and civil society demonstrates that the EGD has a specific focus point on garnering not only the support but also the involvement of these sector players. The proposal also indicates the importance of industry transformation through the adoption of an EU industrial strategy. This identifies specific sectors, from large-scale infrastructure to taxation and social benefits. Additionally, the deal targets 'energy extensive industries' such as steel, chemicals, and cement as being indispensable, and thus decarbonization and modernization become a necessary action point. Being essential policy targets, EU citizens (often referred to as consumers) are identified to raise climate resilience. The just transition mechanism outlines the plan to ensure no one is left behind and contributes to the inclusive protection of "citizens and workers most vulnerable to the transition (European Commission 2019)."

\section{Why (aims)}

The EGD outlines the opportunity to "transform its economy and society to put it on a more sustainable path (European Commission 2019)." Two main principles define the EGD that is broadly described as a growth strategy. That is, the deal hopes "to transform the EU into a fair and prosperous society, with a modern, resource-efficient, and competitive economy" (European Commission 2019) while ensuring that there are no net emissions of greenhouse gases in 2050 and that economic growth is decoupled from resource use. Additionally, the deal outlines the importance of biodiversity and environmental conservation stating that "the EU and its global partners need to halt biodiversity loss." The EGD,

3 The European Green Deal. 2019. European Commission 
therefore, espouses a biodiversity strategy that includes plans for "preserving and restoring Europe's natural capital." This is done through addressing land and sea use and considering "climate change as an important driver of biodiversity loss (European Commission 2019)."

\section{What (contents)}

The EGD comprises plans for infrastructure and plans to include national, municipal, and community infrastructure for climate resilience. The EGD particularly identifies the renovation of schools. The plan also identifies the need for transportation, especially in cities, to reduce pollution. However, this is not necessary to transform transport infrastructure but rather "to revise by June 2021 the legislation on $\mathrm{CO} 2$ emission performance standards for cars and vans (European Commission 2019).” Buildings are subject to the 'renovation wave of public and private buildings, with a focus on the energy performance of buildings. The deal also prioritizes social housing "to help households who struggle to pay their energy bills (European Commission 2019).” The focus should also be put on renovating schools and hospitals, as the money saved through building efficiency will be money available to support education and public health. The EGD emphasizes the measures as targeting citizens in 'all their diversity,' indicating social inclusion. For business sectors, the EGD intends to impose regulation rather than a specific plan to support it through availing of a budget line. To this end, "companies and financial institutions will need to increase their disclosure of climate and environmental data so that investors are fully informed about the sustainability of their investments (European Commission 2019)."

Questions 16 and 17 involve the restructuring of the economy and seek to identify if the GND addresses financial reform and circular economy, both of which are principal components in achieving the goals of the EGD. In this regard, the Commission identifies the importance of the national-level context. Here, the EU GND "will create the context for broad-national based tax reforms, removing subsidies for fossil fuels, shifting the tax burden from labor to pollution, and taking into account social considerations," while also encouraging "member states [to] make a more targeted use of VAT rates to reflect increased environmental ambitions (European Commission 2019)." Embedded within the EGD is "a new circular economy action plan [that] will help modernize the EU's economy and draw benefit from the opportunities of the circular economy domestically and globally (European Commission 2019).” Additionally, the circular economy action plan is set to guide the transition in allsectors. Finally, for the sake of identifying industry transition, the framework asks if there is 
public investment legislative support to transform the transportation sector. It also asks if there is support for farmers in practicing sustainable land use.

The EGD caters to defining a strategy for sustainable and smart mobility. This is primarily legislative support for regulating the transport industry to achieve emission and climate change outcomes. There is also a clear intention for 'fossil fuel subsidies to end' and for the revision of current "tax exemptions including for aviation and maritime fuels (European Commission 2019)." In terms of agriculture and farming, the 'farm to fork' strategy addresses sustainable farming practices and is directly linked to achieving a circular economy in the EU EGD. It includes planned revisions of identified existing policies such as the common agricultural policy and is intended to increase efforts to tackle climate change, protect the environment, and preserve biodiversity.

How (measures)

Implementation of EGD is a focal part of demonstrating the depth of planning that various proposals layout to achieve their goals. The EGD outlines measures for the education of the public through existing institutions of learning. The EGD identifies that "schools, training institutions, and universities are well placed to engage with pupils, parents, and the wider community on the changes needed for a successful transition (European Commission 2019)." Linked with this is the intention to prepare the workforce which questions 23 asks, in order to determine the level of inclusion of job training for industry transition and equal opportunity. The EGD emphasizes that "pro-active reskilling and upskilling are necessary to reap the benefits of the ecological transition (European Commission 2019)." While the strategy outlines the importance of training, the target group is generalized as Europe's workforce.

In terms of research and innovation, the EGD emphasizes this aspect as crucial to achieving various outcomes. "Accessible and interoperable data are at the heart of data-driven innovation (European Commission 2019)." The EGD mentions that "research and innovation facilitate evidence-based decisions and expand the capacity to understand and tackle environmental challenges (European Commission 2019)." At various levels including agriculture and farming, transport and infrastructure improvement, and energy efficiency and transition, emphasis on technological innovation and research is mentioned as key to achieving the sector aims and climate change outcomes. Overall, convening, supporting, and prioritizing evidence-based research becomes a key area in delivering "new technologies, sustainable solutions, and disruptive innovation [that] are critical to achieving the objectives of the European Green Deal (European Commission 2019)." 
International cooperation is emphasized in the EGD. The EGD identifies the $\mathrm{EU}$ as a leader that supports climate actions in other parts of the world. To coin a phrase, the EGD aims to "develop a stronger 'green deal diplomacy' focused on convincing and supporting others to take on their share of promoting more sustainable development (European Commission 2019)." The target entities comprise already existing diplomatic channels "including the United Nations, the G7, G20, the World Trade Organization, and other relevant international fora (European Commission 2019)." The EGD also proposes the support of immediate neighbors as well as fostering partnership with China and supporting a comprehensive strategy with Africa through the African Union.

Finally, regarding funding, our framework seeks to determine if the GND includes mechanisms for public and private investments. The EGD proposes both public and private funding for the international community (global leadership) and for the EU specifically. As a 'Global Leader', the EU outlines that "as public funds will not suffice, the EU and its Member States will coordinate their support to engage with partners to bridge the funding gap by mobilizing private finance (European Commission 2019)." Committing a target to this, the EU Commission proposes to "allocate a target of $25 \%$ of its budget to climate-related objectives." The commission also identified the role of policies in creating an investment environment that achieves participation from the private sector. Locally, within the EU, national budgets will be used more as "green budgeting tools [that] will help to redirect public investment, consumption, and taxation to green priorities and away from harmful subsidies (European Commission 2019)." The EGD identifies several mechanisms through which private and public funding are secured. This includes the European Innovation Council, the Horizon Europe Program, and other existing EU institutions, all intended to bring about sustainable financing to develop a financial system that supports sustainable growth. We illustrate the comparative analysis of GND proposals of the US and the EU in Table 2.

Table 2. Result of the analysis based on the Politics of Green New Deal Framework

\begin{tabular}{ccc}
\hline Politics of GND Questions & European Commission & The United States \\
\hline Who (Actors) & & \\
Policy initiator & Firmly included & Somewhat Included \\
Reflecting opinions of major \\
$\begin{array}{c}\text { actors } \\
\text { Role of the municipal government } \\
\text { Policy target }\end{array}$ & Firmly included & Firmly included \\
& Somewhat included & Somewhat included \\
\end{tabular}




\begin{tabular}{|c|c|c|}
\hline Politics of GND Questions & European Commission & The United States \\
\hline $\begin{array}{l}\text { Economic and climate change, } \\
\text { vulnerable communities }\end{array}$ & Somewhat included & Firmly included \\
\hline \multicolumn{3}{|l|}{ Why (Aims) } \\
\hline Mitigation goal & Firmly included & Firmly included \\
\hline $\begin{array}{l}\text { Biodiversity and environmental } \\
\text { conservation }\end{array}$ & Firmly included & Somewhat included \\
\hline Climate resilience & Firmly included & Firmly included \\
\hline Quality job creation & Firmly included & Firmly included \\
\hline Green growth & Firmly included & Somewhat included \\
\hline Reducing social inequality & Firmly included & Firmly included \\
\hline Improving the standard of living & Somewhat included & Firmly included \\
\hline \multicolumn{3}{|l|}{ What (Contents) } \\
\hline Infrastructure building & Firmly included & Firmly included \\
\hline $\begin{array}{l}\text { Community-based infrastructure } \\
\text { building for climate change } \\
\text { resilience }\end{array}$ & Somewhat included & Somewhat included \\
\hline Energy transition & Firmly included & Firmly included \\
\hline Restructuring the economy & Firmly included & Somewhat included \\
\hline Circular Economy & Firmly included & Somewhat included \\
\hline $\begin{array}{l}\text { Industry transition for public } \\
\text { transportation }\end{array}$ & Somewhat included & Firmly included \\
\hline Industry transition for agriculture & Firmly included & Firmly included \\
\hline Industry transition for trade & Somewhat included & Somewhat included \\
\hline \multicolumn{3}{|l|}{ How (Measures) } \\
\hline Education on climate change & Somewhat included & Somewhat included \\
\hline Job training (social equality) & Firmly included & Firmly included \\
\hline Research and Innovation & Firmly included & Firmly included \\
\hline International cooperation & Firmly included & Somewhat included \\
\hline Funding mechanism & Firmly included & Somewhat included \\
\hline
\end{tabular}

Note: Firmly included: both identification and contents; Somewhat included: identification but no contents; Not included: neither identification nor contents. Source: Made by authors 


\section{Discussion}

In terms of the 'who' questions, GND initiators and targets are included in the EU and US proposals. Both proposals identify the federal government and the European Commission as primary policy actors with support from the parliament and other authorities. However, only the EU GND clearly laid out the role of local authorities in building citizen dialogue with local energy communities according to the climate pact. Compared to the EU proposal, US GND listed 'local authorities' as a series of administrative levels, such as local, state, and federal levels. Naming the key actors is important and both proposals do so adeptly, however, the key distinction is the 'action item' that the EU proposal offers. Specifically, fostering dialogue demonstrates an understanding of the importance of bridging the gap between local communities and respective local authorities. This becomes inescapable when ensuring a just transition that is workable from the grassroots level. Regarding GND aims, both the US and EU GNDs emphasize climate change mitigation, resilience, sustainable job creation, and fair and just transition. These five elements constitute the core purposes of both GNDs. However, the two components are different. The EU GND identifies biodiversity and traditional environmental conservation as primary aims. Likewise, decoupling greenhouse gas emission reduction from economic growth is one of the key aims of the EU GND.

Regarding content, the US and EU proposals share similarities in infrastructure building and energy transition. The EU proposal highlights the importance of the circular economy, while the US proposal makes the transition to clean and public transportation. Another difference centers around tax reform. The EGD proposes tax reform and outlines putting a heavier burden on fossil fuel energy use and pollution to meet the net-zero target.

To implement GND policies, concrete and comprehensive measures are critical. Specific emphasis on the job training and research and development are common in the US and EU proposals. In terms of funding mechanisms, the EU proposal provides more detailed funding sources for GND implementation. However, the US proposal does not specify funding sources and mechanisms. In addition, compared to the emphasis on the international cooperation scheme in the EGD, the US GND symbolically declares the value of the international exchange of technology and other services to make the US the climate leader and to help other countries without outlining a clear scheme.

This research compared the documents of each GND proposal, using the framework questions presented in Table 1. Each question is evaluated based on the proposed framework on the scale of not answered/somewhat answered/fully answered. The two criteria for the scale are identification and contents. 
Identification refers to whether the contents have mentioned, defined, and proposed what the question posed in the framework is asking. Contents refer to the degree of comprehensiveness of the proposed actors, aims, contents, and measures.

The EGD, although it is a regional body, goes into the significant details of what contents are involved and howaims are to be achieved. A significant difference from the US GND, as will be demonstrated below, is often setting baseline information and numerical targets for projected interventions. Additionally, the heavy emphasis on the GND being the corporate responsibility of not only the EU but also global actors is a recurring reference point for its success or failure. Thus, the commission emphasizes the EU's need to demonstrate leadership and partnership to protect gains and reduce "leakage" to realize the consolidated rewards of GNDs globally. This aspect of focusing on how aims are to be achieved could be reflective of a greater political will and interest in global partnership. The EU proposal notes key actors outside of itself and this indicates a strong interest in participating in green transition as a primary player but also a supporter in global climate change concerns. This further opens opportunities for greater participation of the EU in not only regional but global institutions addressing climate change.

\section{Conclusion}

Using the fundamental questions of politics, we suggest subcomponents and questions for GND, including actors, aims, contents, and measures. This framework can be applied to analyze GND proposals from other countries. Empirically, our comparative study suggests detailed contents, measurable targets, international cooperation schemes, and funding sources. concrete and well-planned funding sources and mechanisms for transition are the linchpins of the government stimulus package. Without funding and investment, the GND proposals become unmaterialized wish lists. Proper measures with comprehensive and concrete actors, aims, and contents could enable the implementation of the GND proposals. To this end, a detailed action plan for GND should follow the vision statement proposals.

This study draws policy implications for designing GND at the local and national levels. First, clearly defined actors (policy initiators, and target or collaborators), comprehensive and concrete aims, contents, and measures are imperative for effective green stimulus and climate change response. This framework can be applied to design national and local level GND as well as to be 
an evaluating toolkit. In addition, if the local or national GND can answer who gets what, why, and how, communication with citizens would become much easier. Second, to implement the GND initiative, implementing organization and budget (funding) should be prepared at the initial designing stage. Otherwise, it would be challenging to persuade politicians, bureaucrats, experts, companies, and citizens. Furthermore, clarifying the potential benefits of GND with tangible aims could garner supports from society.

Limitations of this study are gaps that can be filled in future research. First, as several countries (such as Canada, Australia, and currently Biden's US government) consider GND institutionalization, the longitudinal extension and cross-sectional expansion of comparative studies would examine the differences and similarities of GNDs in different contexts. Second, examining the causal mechanism of GND adoption/non-adoption would help us improve our understanding of the effectiveness of GND proposals. The EU proposal has been adopted, while the US proposal has not. However, we expect to see significant changes in US GND policy development during the Biden administration. Third, the effectiveness of the GND plan should be evaluated in the future. Ambitious proposals should be effectively implemented. To this end, developing a policy evaluation scheme for GND could ensure the effectiveness of sustainability improvement as well as economic prosperity through job creation and innovation. In this regard, future research could investigate how our analytic framework on comprehensiveness and concreteness has an impact on effective GND implementation and performance. Fourth, In July 2020, the South Korean government declared Korean Green New Deal with a budget of 42.7 trillion Korean Won for green energy and infrastructure by creating 659,000 jobs (Government of the Republic of Korea 2020). It is the first commitment for a stimulus package toward low carbon and green economy in Asia (Lee and Woo 2020). Future research applying GND political analysis framework into Korean GND would enhance our understandings of environmental politics and policy making in a comparative manner. Fifth, by expanding case studies, analytic framework and related questions could be updated to be logically coherent and exhaustive to cover all components. Examining the interaction of each component (e.g. which actors with which aims, contents, and measures could bring different outcomes) would provide a dynamics framework of GND politics. 


\section{REFERENCES}

Albert, Michael J. 2020. “The Dangers of Decoupling: Earth System Crisis and the 'Fourth Industrial Revolution.”' Global Policy11 (2). Blackwell Publishing Ltd: 245-54. doi:10.1111/1758-5899.12791.

Aşici, Ahmet Atil, and Zeynep Bünül. 2012. "Green New Deal: A Green Way out of the Crisis?” Environmental Policy and Governance 22 (5): 295-306. doi:10.1002/eet.1594.

Bang, Guri, and Miranda A Schreurs. 2010. A Green New Deal Framing US Climate Leadership. 1st ed. Routledge. http://ebookcentral.proquest.com.

Barbier, Edward B. 2010. "Global Governance: The G20 and a Global Green New Deal." Economics: The Open-Access 4 (2010-2): 1-35. doi:http://dx.doi.org/10.5018/economics-ejournal.ja.2010-2.

Bauhardt, Christine. 2014. "Solutions to the Crisis? The Green New Deal, Degrowth, and the Solidarity Economy: Alternatives to the Capitalist Growth Economy from an Ecofeminist Economics Perspective." Ecological Economics 102: 60-68. doi:10.1016/j.ecolecon.2014.03.015.

Bloomfield, Jon, and Fred Steward. 2020. "The Politics of the Green New Deal." Political Quarterly91 (4): 770-79. doi:10.1111/1467-923X.12917.

Chohan, U.W., 2019. A green new deal: Discursive review and appraisal. Notes on the 21st Century (CBRI).

Dauncey, Guy. 2019. “Ten Green New Deals - How Do They Compare?” The Practical Utopian. https:/thepracticalutopian.ca/2019/09/27/ten-green-new-deals -how-do-they-compare/.

Elliott, Larry, Colin Hines, Tony Juniper, Jeremy Leggett, Caroline Lucas, Richard Murphy, Ann Pettifor, Charles Secrett, and Andrew Simms. 2008. "A Green New Deal Joined-up Policies to Solve the Triple Crunch of the Credit Crisis, Climate Change and High Oil Prices.” The Green New Deal Group.

European Parliament. The European Green Deal. 2019/2956(RSP). Introduced on December 11, 2019. https://www.europarl.europa.eu/doceo/document/ TA-9-2020-0005_EN.html.

Fitz, Don. 2014. "How Green Is the Green New Deal?" Green Social Thought 65: A Magazine of Synthesis and Regeneration.

Galvin, Ray, and Noel Healy. 2020. "The Green New Deal in the United States: What It Is and How to Pay for It.” Energy Research and Social Science 67 (December 2019). doi:10.1016/j.erss.2020.101529.

Government of the Republic of Korea. 2020. "Korean New Deal: National Strateg y for a Great Transformation.” https://english.moef.go.kr/pc/selectTbPre 
ssCenterDtl.do?boardCd=N0001\&seq $=4948$.

H.Res.109 Recognizing the Duty of the Federal Government to Create a Green New Deal. 2019. 116th Congress. https://www.congress.gov/bill/116thcongress/house-resolution/109/text.

Hickel, Jason, and Giorgos Kallis. 2019. "Is Green Growth Possible?” New Politica 1 Economy3467. Taylor \& Francis. doi:10.1080/13563467.2019.1598964.

Holtz-Eakin, Douglas, Dan Bosch, Ben Gitis, Dan Goldbeck, and Philip Rossetti. 2019. "The Green New Deal: Scope, Scale, and Implications." American Action Forum. https://www.americanactionforum.org/research/the-greennew-deal-scope-scale-and-implications/.

House of Commons. Decarbonisation and Economic Strategy. Bill 155 2019-21. Introduced on July 7, 2020. https://publications.parliament.uk/pa/bills/ cbill/2017-2019/0365/190365.pdf.

IPCC. 2014. "AR5 Climate Change 2014: Mitigation of Climate Change." Cambridge, United Kingdom and New York, NY, USA. https://www.ipcc.ch/site/assets/uploads/2018/02/ipcc_wg3_ar5_full.pdf.

Jenkins, Tim, and Andrew Simms. 2012. "PAPER 1 : THE GREEN ECONOMY." https://sf.stakeholderforum.org/fileadmin/files/PAPER 1_Green Economy_Final_vj.pdf.

Jha, Shikha, Sonia Chand Sandhu, and Radtasiri Wachirapunyanont. 2018. "Inclusive Green Growth Index: A New Benchmark for Quality of Growth." doi:10.22617/TCS189570-2.

Lasswell, Harold Dwight. 1936. Politics: Who Gets What, When, How. Whittlesey House, McGraw-Hill Book Company. doi:10.5840/zfs193761185.

Lee, Jae Hyup, and Jisuk Woo. 2020. "Green New Deal Policy of South Korea: Policy Innovation for a Sustainability Transition.” Sustainability (Switzerland). MDPI AG. doi:10.3390/su122310191.

Lee, Taedong, and Taehwa Lee. 2016. "Evolutionary Urban Climate Resilience: Assessment of Seoul's Policies." International Journal of Climate Change Strategies and Management 8 (5). Emerald Group Publishing Ltd.: 597612. doi:10.1108/IJCCSM-06-2015-0066.

Lee, Taedong. 2017. "The Effect of Clean Energy Regulations and Incentives on Green Jobs: Panel Analysis of the United States, 1998-2007." Natural Resources Forum 41 (3). John Wiley \& Sons, Ltd: 145-55. doi:10.1111/1477-8947.12125.

Luke, Timothy W. 2009. "A Green New Deal: Why Green, How New, and What Is the Deal?" Critical Policy Studies 3 (1). Informa UK Limited: 14-28. doi:10.1080/19460170903158065.

MacArthur, Julie L., Christina E. Hoicka, Heather Castleden, Runa Das, and 
Jenny Lieu. 2020. "Canada's Green New Deal: Forging the Socio-Political Foundations of Climate Resilient Infrastructure?” Energy Research and Social Science. Elsevier Ltd. doi:10.1016/j.erss.2020.101442.

Martinez-Fernandez, Cristina, Carlos Hinojosa, and Gabriela Miranda. 2010. "Green Jobs and Skills: The Local Labour Market Implications of Addressing Climate Change.” www.oecd.org/dataoecd/54/43/44683169.pdf?conte.

Nersisyan, Yeva, and L. Randall Wray. 2020. "Can We Afford the Green New Deal?” Journal of Post Keynesian Economics. Routledge. doi:10.1080/01603477.2020.1835499.

Nugent, James Patrick. 2011. "Changing the Climate: Ecoliberalism, Green New Dealism, and the Struggle over Green Jobs in Canada." Labor Studies Journal. doi:10.1177/0160449X10392528.

O’Neill, Daniel W. 2020. “Beyond Green Growth.” Nature Sustainability 3 (4). Springer Science and Business Media LLC: 260-61. doi:10.1038/s41893-020-0499-4.

OECD. 2011. Towards Green Growth. OECD Green Growth Studies. OECD. doi:10.1787/9789264111318-en.

Pettifor, Ann. 2019. The Case for the Green New Deal. Verso.

Reddy, P. Parvatha. 2015. Climate Resilient Agriculture for Ensuring Food Security. Climate Resilient Agriculture for Ensuring Food Security. Springer India. doi:10.1007/978-81-322-2199-9.Rifkin, Jeremy. 2019. The Green New Deal Why the Fossil Fuel Civilization Will Collapse by 2028, and the Bold Economic Plan to Save Life on Earth. St. Martin's Publishing Group.

The European Green Deal. 2019. EUROPEAN COMMISSION. https://eur-lex.europa.eu/legal-content/EN/TXT/?qid=1576150542719\&u $\mathrm{ri}=\mathrm{COM} \% 3 \mathrm{~A} 2019 \% 3 \mathrm{~A} 640 \% 3 \mathrm{AFIN}$.

The Green New Deal for Europe. "10 Pillars of the Green New Deal for Europe.” Accessed April 15. https://www.gndforeurope.com/10-pillars-of-the-greennew-deal-for-europe.

The Green New Deal Group. “Our Core Principles.” Accessed at https://greennew dealgroup.org/principles/ (June 7).

The Sunrise Movement. "Green New Deal Strategy." Accessed https://www.sunrisemovement.org/gnd-strategy (June 7).

Tienhaara, Kyla. 2014. "Varieties of Green Capitalism: Economy and Environment in the Wake of the Global Financial Crisis." Environmental Politics 23 (2). Routledge: 187-204. doi:10.1080/09644016.2013.821828.

Tienhaara, Kyla. 2016. "Governing the Global Green Economy." Global Policy 7 (4): 481-90. doi:10.1111/1758-5899.12344.

U.S. Congress. House. Recognizing the duty of the Federal Government to create 
a Green New Deal. H.Res.109. 116th Cong., 1st sess. Introduced in House February 7, 2019. https://www.congress.gov/bill/116th-congress/houseresolution/109/text.

United Nations Environment Programme. 2008. "Background Paper on Green Jobs.” UNEP Background Paper. http://www.unep.org/labour_environment/ pdfs/green-jobs-background-paper-18-01-08.pdf.

World Trade Organization (WTO), and United Nations Environment Programme(UNEP). 2018. "Making Trade Work for the Environment, Prosperity and Resilience."

[Received May 31, 2021; Revised Jul 9, 2021; Accepted Jul 9, 2021] 